\title{
Clinical Significance of Serum Levels of Vascular Endothelial Growth Factor, Angiopoietin-1, and Angiopoietin-2 in Patients with Rheumatoid Arthritis
}

\author{
DAITARO KUROSAKA, KENICHIRO HIRAI, MAKIKO NISHIOKA, YUKIO MIYAMOTO, KEN YOSHIDA, \\ KENTARO NODA, TARO UKICHI, MAIMI YANAGIMACHI, KAZUHIRO FURUYA, EIGO TAKAHASHI, \\ ISAMU KINGETSU, KUNIHIKO FUKUDA, and AKIO YAMADA
}

\begin{abstract}
Objective. To evaluate the clinical significance of serum levels of vascular endothelial growth factor (VEGF), angiopoietin-1 (Ang-1), and angiopoietin-2 (Ang-2) in patients with rheumatoid arthritis (RA).

Methods. The subjects were 70 patients with RA. Serum VEGF, Ang-1, and Ang-2 levels were determined by ELISA. As indices of disease activity, serum levels of C-reactive protein (CRP) and matrix metalloprotease (MMP)-3 were examined, and the 28-joint count Disease Activity Score (DAS28)-CRP was calculated. Power Doppler ultrasonography was performed in the bilateral wrists, elbows, shoulders, knees and ankles. The synovial blood flow signals were scored using a 3-grade scale (0-2), and the total of the scores in the 10 joints was regarded as the total signal score (TSS).

Results. Serum VEGF level showed significant correlations with serum CRP and MMP-3 levels, DAS28-CRP, and TSS. Serum Ang-1 level showed significant correlations with serum MMP-3 level and DAS28-CRP. Serum Ang-2 level showed significant correlations with serum CRP level and TSS.

Conclusion. The serum VEGF level is important as an index of the activity of RA based on angiogenesis and a prognostic factor regarding joint destruction. Serum Ang-1 level may be useful as an index of sustained arthritis based on the maintenance of newly formed vessels. Serum Ang-2 level may reflect a state of marked angiogenesis. (First Release May 1 2010; J Rheumatol 2010; 37:1121-8; doi:10.3899/jrheum.090941)
\end{abstract}

\section{Key Indexing Terms: \\ VASCULAR ENDOTHELIAL GROWTH FACTOR CLINICAL PRACTICE}

\section{RHEUMATOID ARTHRITIS} ANGIOPOIETIN

Rheumatoid arthritis (RA) is a disease characterized by the chronic inflammation of joint synovial tissues. Inflammatory synovial tissue is called pannus. At such sites, many newly formed vessels are observed ${ }^{1-3}$. Angiogenic factors such as vascular endothelial growth factor (VEGF), angiopoietin-1 (Ang-1), and angiopoietin-2 (Ang-2) play important roles in the angiogenesis of pannus ${ }^{3}$.

VEGF is particularly important ${ }^{4}$. It promotes angiogene-

From the Division of Rheumatology and the Division of Radiology, Department of Internal Medicine, Jikei University School of Medicine, Tokyo, Japan.

D. Kurosaka, MD; K. Hirai, MD; K. Yoshida, MD; K. Noda, MD; T. Ukichi, MD; M. Yanagimachi, MD; K. Furuya, MD; E. Takahashi, MD, I. Kingetsu, MD; A. Yamada, MD, Division of Rheumatology, Department of Internal Medicine, Jikei University School of Medicine; M. Nishioka, MD; Y. Miyamoto, MD; K. Fukuda, MD, Division of Radiology,

Department of Internal Medicine, Jikei University School of Medicine.

Address correspondence to Dr. D. Kurosaka, Division of Rheumatology, Department of Internal Medicine, Jikei University School of Medicine, 3-25-8, Nishishinbashi, Minato-ku, Tokyo, Japan.

E-mail:d_kurosaka@jikei.ac.jp

Full Release Article. For details see Reprints/Permissions at jrheum.org Accepted for publication February 17, 2010. sis by acting on vascular endothelial cells and promoting endothelial cell migration and lumen formation ${ }^{5}$. In patients with RA, VEGF is detected in joints and serum, and is considered to be closely related to the development of pathologic features of arthritis and especially angiogenesis ${ }^{6-8}$.

Ang-1 and Ang-2 contribute to adhesion and detachment between vascular endothelial and wall cells ${ }^{9}$. Ang-1 is constantly secreted from wall cells when blood vessels are stable. Ang- 1 is bound to Tie 2 on endothelial cells, and this binding is related to the binding between vascular endothelial and wall cells. But the detachment of vascular endothelial and wall cells is necessary for the initiation of angiogenesis. At their detachment, Ang-2, an endogenous antagonist molecule highly homologous to Ang-1, is secreted by vascular endothelial cells and induces the inactivation of Tie 2 by inhibiting the binding between Ang- 1 and Tie2. As a result, the adhesion between vascular endothelial and wall cells is inhibited, and angiogenesis is initiated. In this state, Ang-2 is dominant over Ang-1. Once new vessels have been formed, their stabilization becomes important. Adhesion between vascular endothelial and wall cells becomes necessary again to stabilize the newly formed vessels. Therefore,

Personal non-commercial use only. The Journal of Rheumatology Copyright (c) 2010. All rights reserved. 
Ang-1 is secreted again by wall cells and binds with Tie 2 on endothelial cells. In this state, Ang-1 is dominant over Ang-2 ${ }^{10-14}$.

Experiments using synovial tissues from patients with RA have confirmed the roles of Ang-1 and Ang-2 in angiogenesis ${ }^{15-17}$. Both have been observed to be important but to act in different periods. Ang-1 has been observed to be important for the maintenance of blood vessels, and Ang-2 to play a role at sites of marked angiogenesis.

While VEGF, Ang-1, and Ang-2 are connected to angiogenesis in synovial regions, the clinical significance of their levels in serum is unclear. The serum level of VEGF has been observed to serve as an index of the severity of joint destruction in RA, but there have been few studies concerning the levels of serum Ang-1 or Ang-2. One study said that the serum Ang-1 level was correlated with the erythrocyte sedimentation rate $^{8}$. In addition, there has been no research on simultaneous measurement of serum levels of VEGF, Ang-1, and Ang-2, with evaluation of their relationships. In our study, therefore, we simultaneously measured the serum levels of these 3 factors in patients with RA and evaluated their relationships with indices of RA activity.

\section{MATERIALS AND METHODS}

The subjects were 70 patients (55 women and 15 men) with RA who fulfilled the diagnostic criteria of the American College of Rheumatology $(1987)^{18}$. The mean age of the subjects was $56.2 \pm 13.5$ (range 24-85) years. The study was approved by the Ethical Committee of Jikei University School of Medicine in advance. Informed consent was obtained from all patients.

Measurement of serum levels of angiogenic factors. The serum samples were stored at $-40^{\circ} \mathrm{C}$, and measurements were performed within 3 months after collection. Serum VEGF, Ang-1, and Ang-2 levels were determined using an ELISA kit (R\&D Systems, Minneapolis, MN, USA). The mean values of double measurements were calculated.

Ultrasonography assessment. Power Doppler ultrasonography (PDUS) was performed in the dark. Ultrasound was emitted with a linear array transducer (10 MHz; GE Healthcare, Waukesha, WI, USA). The pulse repetition frequency was set at the lowest level in the tolerated range to achieve the maximum sensitivity, 500-750 Hz. Low wall filters were used. The dynamic range was set at $20-40 \mathrm{~dB}$. PDUS was performed in a total of 10 joints: the bilateral shoulders, elbows, wrists, knees, and ankles. The probe was applied to the posterior recess, biceps tendon sheath and subdeltoid bursa in the shoulder, anterior and posterior recesses in the elbow, dorsal carpal recesses, extensor tendon sheaths and flexor tendon sheaths in the wrist, suprapatellar, medial parapatellar and lateral parapatellar recesses in the knee, and anterior, medial and lateral tendon sheaths in the ankle. After PDUS, video clips recorded by 2 operators were analyzed. The clinical conditions and examination data of the analyzed patients were concealed from the analyzers. The blood flow signals at various sites of the synovial membrane were graded and scored as follows: grade 1: no flow (0 point); grade 2: mild or moderate flow (1 point); grade 3 : intense flow ( 2 points). The score at the site with the strongest finding in each joint was adopted as the score of the joint, and the total of the scores of the 10 joints was defined as the total signal score (TSS).

Statistical analysis was performed using Graphpad Prism software (Version 4.0). The relationships of clinical data and findings on ultrasonography were analyzed using Spearman's rank correlation test. $\mathrm{P}<0.05$ was considered significant.

\section{RESULTS}

Patients' characteristics. Table 1 shows the patients' characteristics. The duration of the disease was $4.43 \pm 4.81$ years (mean \pm SD). The duration was within 1 year after the onset in $14,1-5$ years in $29,5-10$ years in 17 , and 10 years or longer in 9.

The dose of oral prednisolone was $0 \mathrm{mg}$ in 29 patients, 5 $\mathrm{mg}$ or less in $11,5-10 \mathrm{mg}$ in 21 , and $10 \mathrm{mg}$ or more in 10 . The dose of methotrexate was $0 \mathrm{mg}$ in 33 patients, $0-4 \mathrm{mg}$ in 7, 4-8 $\mathrm{mg}$ in 22 , and $8 \mathrm{mg}$ or more in 8 . Biological preparations were used in 7 patients. The mean serum $\mathrm{C}$-reactive protein $(\mathrm{CRP})$ level was $2.166 \pm 3.27 \mathrm{mg} / \mathrm{dl}$, the mean serum matrix metalloprotease (MMP)-3 level was $1.77 \pm 41 \mathrm{ng} / \mathrm{ml}$, and mean 28-joint count Disease Activity Score (DAS28)-CRP was 3.324 \pm 1.12 . DAS28-CRP was $1-2$ in 8 patients, 2-3 in 20, 3-4 in 26, 4-5 in 9, 5-6 in 6, and 6-7 in 1 patient. The mean serum VEGF level was $620.46 \pm 567.3$ pg/ml, mean serum Ang-1 level was 35,975.08 \pm 11,200.65 $\mathrm{pg} / \mathrm{ml}$, and mean serum Ang-2 level was 3,377.614 \pm $1,434.909 \mathrm{pg} / \mathrm{ml}$.

Serum levels of angiogenic factors and indices of disease activity. Figure 1 shows the relationships of the serum VEGF level with the serum CRP and MMP-3 levels, DAS28-CRP, and TSS. The serum VEGF level was significantly correlated with the serum CRP level $(\mathrm{r}=0.5013, \mathrm{p}<$ $0.0001)$, serum MMP-3 level $(\mathrm{r}=0.3567, \mathrm{p}=0.0033)$, DAS28-CRP $(r=0.6527, p<0.0001)$, and TSS $(r=0.4824$, $\mathrm{p}<0.0001)$.

Figure 2 shows the relationships of the serum Ang-1 level with the serum CRP and MMP-3 levels, DAS28-CRP, and TSS. It was correlated with the serum MMP-3 level ( $\mathrm{r}=$ $0.3121, \mathrm{p}=0.0135)$ and DAS28-CRP $(\mathrm{r}=0.2435, \mathrm{p}=$ $0.0489)$, but not with the serum CRP level $(\mathrm{r}=0.1923, \mathrm{p}=$ $0.1218)$ or TSS $(r=0.1567, p=0.2088)$.

Figure 3 shows the relationships of the serum Ang-2 level with the serum CRP and MMP-3 levels, DAS28-CRP, and TSS. Serum Ang-2 was significantly correlated with the serum CRP level $(\mathrm{r}=0.3288, \mathrm{p}=0.0055)$ and TSS $(\mathrm{r}=$ $0.2790, \mathrm{p}=0.0193$ ), but not with the serum MMP-3 level $(\mathrm{r}=0.1035, \mathrm{p}=0.4081)$ or DAS28-CRP $(\mathrm{r}=0.2147, \mathrm{p}=$ $0.0743)$.

Relationships among angiogenic factors. Figure 4 shows the relationships among the serum levels of angiogenic factors. A significant correlation $(r=0.3005, p=0.0142)$ was noted between VEGF and Ang-1 but not between VEGF and Ang-2 ( $\mathrm{r}=0.1429, \mathrm{p}=0.2378)$ or between Ang-1 and Ang$2(\mathrm{r}=0.02165, \mathrm{p}=0.8630)$.

\section{DISCUSSION}

We noted increases in the serum levels of angiogenic factors in patients with RA. These factors were correlated with at least 1 of the serum CRP level, serum MMP-3 level ${ }^{19}$, DAS28-CRP ${ }^{20}$, and $\mathrm{TSS}^{21-23}$, which are considered to reflect the activity of RA. These factors have been observed 
Table 1. Scores of blood signals and clinical data.

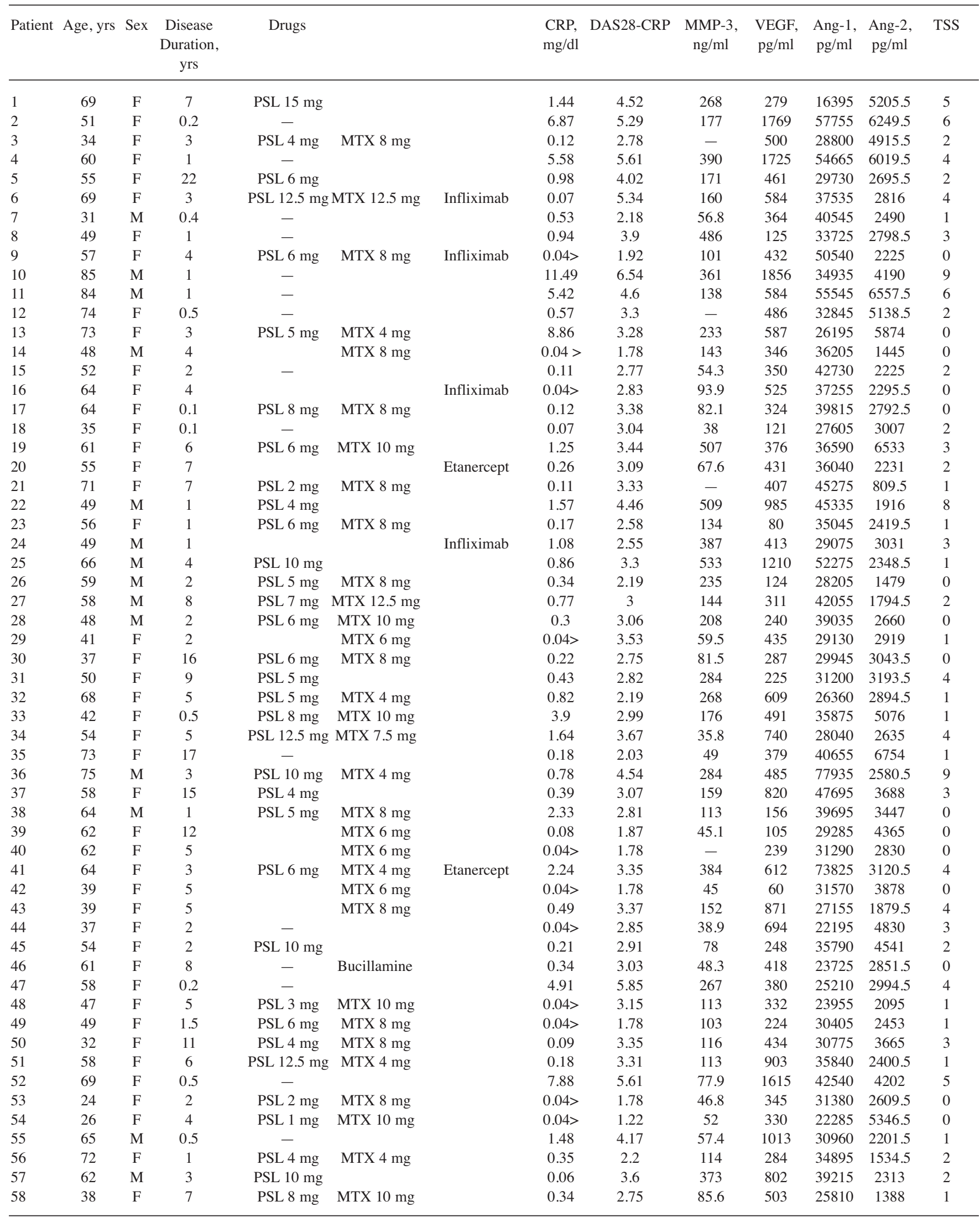


Table 1. Continued.

\begin{tabular}{|c|c|c|c|c|c|c|c|c|c|c|c|c|c|}
\hline Patient & Age, yrs & Sex & $\begin{array}{c}\text { Disease } \\
\text { Duration, } \\
\text { yrs }\end{array}$ & Drugs & & & $\begin{array}{l}\mathrm{CRP} \\
\mathrm{mg} / \mathrm{dl}\end{array}$ & DAS28-CRP & $\begin{array}{l}\text { MMP-3, } \\
\mathrm{ng} / \mathrm{ml}\end{array}$ & $\begin{array}{l}\text { VEGF, } \\
\mathrm{pg} / \mathrm{ml}\end{array}$ & $\begin{array}{l}\text { Ang-1, } \\
\mathrm{pg} / \mathrm{ml}\end{array}$ & $\begin{array}{l}\text { Ang-2, } \\
\mathrm{pg} / \mathrm{ml}\end{array}$ & TSS \\
\hline 60 & 69 & F & 2 & PSL 8 mg & MTX 8 mg & Infliximab & 7.39 & 3.21 & 99.9 & 703 & 35460 & 3349.5 & 3 \\
\hline 61 & 54 & F & 0.5 & PSL $15 \mathrm{mg}$ & & & 0.92 & 4.36 & 219 & 2335 & 40750 & 4889.5 & 2 \\
\hline 62 & 55 & $\mathrm{~F}$ & 7 & PSL 8 mg & MTX 10 mg & & 0.3 & 3.81 & 215 & 1162 & 38020 & 3212.5 & 4 \\
\hline 65 & 43 & $\mathrm{~F}$ & 0.5 & PSL $1 \mathrm{mg}$ & MTX $8 \mathrm{mg}$ & & $0.04>$ & 2.34 & 55.8 & 411.3 & 41330 & 3780 & 0 \\
\hline 66 & 71 & $\mathrm{~F}$ & 0.1 & - & & & 6.76 & 3.74 & 146 & 2602 & 25440 & 2650 & 7 \\
\hline 67 & 73 & M & 0.5 & - & & & 3.13 & 4.79 & 279 & 734 & - & 3879.5 & 6 \\
\hline 68 & 69 & $\mathrm{~F}$ & 10 & & Bucillamine & & 12.12 & 4.81 & 278 & 660 & - & 4461 & 4 \\
\hline 69 & 57 & F & 7 & PSL 10 mg & & & 0.18 & 2.82 & 134 & 137 & - & 3554 & 3 \\
\hline 70 & 56 & $\mathrm{~F}$ & 20 & PSL 8 mg & MTX 8 mg & & 0.48 & 3.48 & 151 & 561 & - & 2148 & 0 \\
\hline
\end{tabular}

CRP: C-reactive protein; MMP-3: matrix metalloproteinase-3; VEGF: vascular endothelial growth factor; Ang-1: angiopoietin-1; Ang-2: angiopoietin-2; DAS: disease activity score; TSS: total signal score; PSL: prednisolone; MTX: methotrexate.
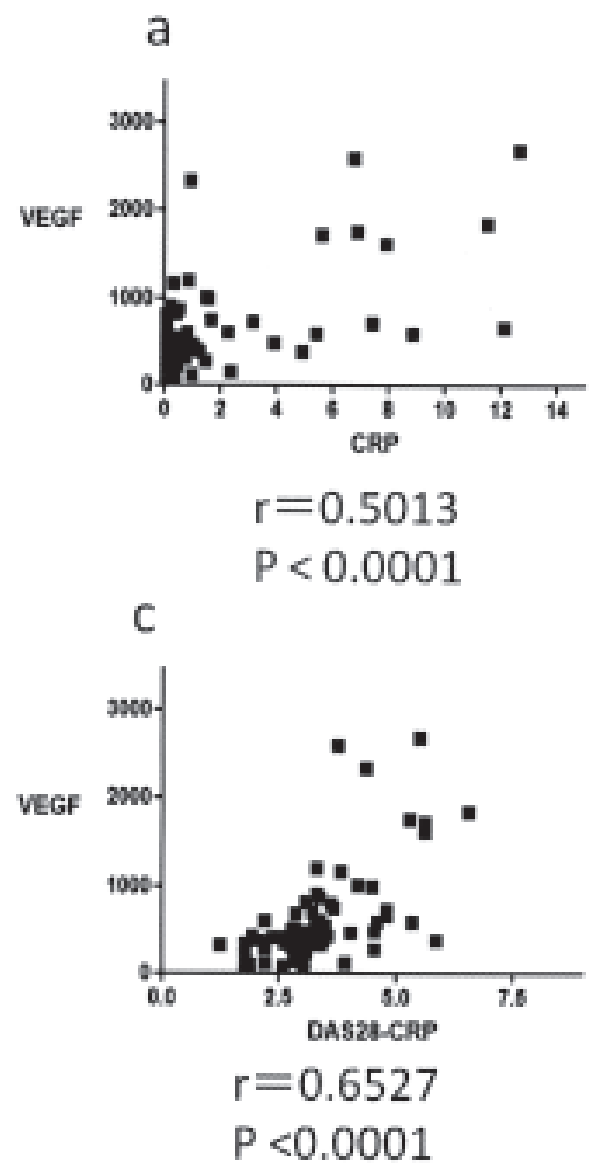
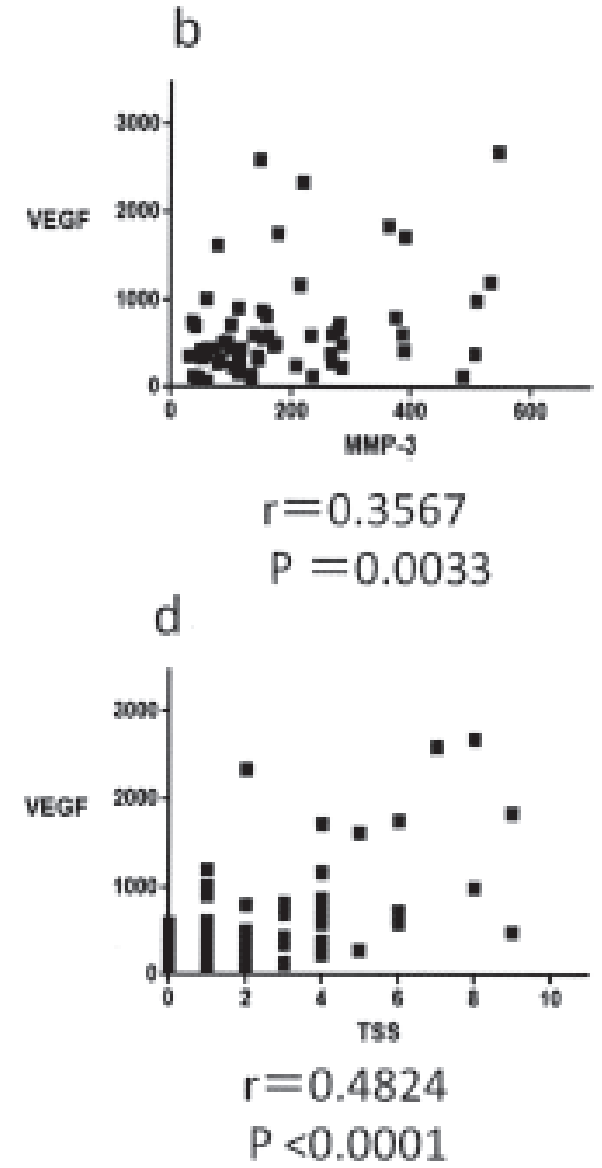

Figure 1. Relationships of the serum vascular endothelial growth factor (VEGF) level with indices of rheumatoid arthritis activity. (a) Serum VEGF and C-reactive protein (CRP) levels. (b) Serum VEGF and matrix metalloprotease (MMP)-3 levels. (c) Serum VEGF level and the 28-joint count Disease Activity Score (DAS28)-CRP. (d) Serum VEGF level and total signal score (TSS). Serum VEGF level was correlated with the serum CRP and MMP-3 levels, DAS28-CRP, and TSS. 

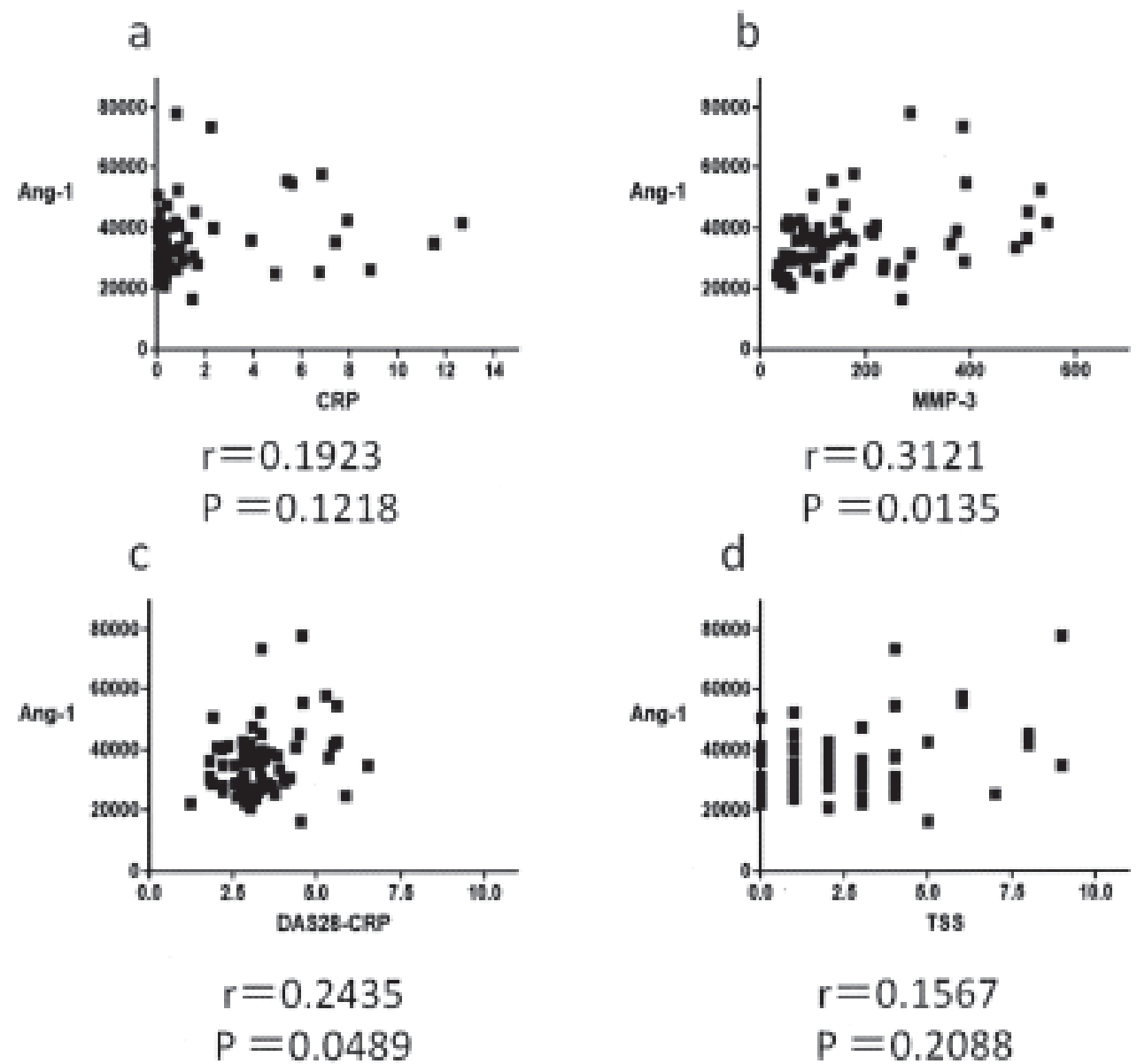

Figure 2. Relationships of the serum angiopoietin-1 (Ang-1) level with indices of RA activity. (a) Serum Ang-1 and C-reactive protein (CRP) levels. (b) Serum Ang-1 and matrix metalloprotease (MMP)-3 levels. (c) Serum Ang-1 level and the 28-joint count Disease Activity Score (DAS28)-CRP. (d) Serum Ang-1 level and total signal score (TSS). Serum Ang-1 level was correlated with the serum MMP-3 level and DAS28-CRP. It was not correlated with the serum CRP level or TSS.

to increase in inflamed areas of the synovial membrane in patients with RA. Therefore, part of the increases in the angiogenic factors observed in this study is considered to have been due to their release from inflamed synovial membrane, although not all of their sources could be determined.

The serum VEGF level was correlated with the serum CRP and MMP-3 levels, DAS28-CRP, and TSS. The serum VEGF level has been observed to be correlated with the serum CRP level ${ }^{7}$ and DAS $28^{8}$, but the relationship between the serum VEGF and MMP-3 levels has not been observed. The serum MMP-3 level is useful as a predictive factor for joint destruction ${ }^{24}$. The serum VEGF level has been observed by radiographic analysis to be an index of joint destruction $^{8}$. Thus, as both the serum VEGF and MMP-3 levels have been observed to reflect joint destruction, their correlation may be explained from this perspective.

In addition to our 2009 study $^{25}$, Strunk, et $a l^{26}$ observed the relationship between the serum VEGF level and syn- ovial blood flow signals. We observed that the serum VEGF level was correlated with the synovial blood flow signal level in the wrist, but Strunk, et al did not observe such a correlation. In these 2 studies, evaluation was made of the wrists alone. While the serum VEGF level is a systemic finding, the synovial blood flow signals of the wrist are local findings. Therefore, evaluation of various joints of the body was considered necessary to examine the relationship between serum VEGF level and synovial blood flow signals. So we examined multiple joints. The number of patients was also markedly increased. As a result, a correlation between the serum VEGF level and TSS could be confirmed. The increase in synovial blood flow signals has been observed histologically to be caused by an increase in the number of blood vessels in the synovial tissue, i.e., angiogenesis ${ }^{27}$. Thus, the correlation between the serum level of VEGF, which is a major angiogenic factor, and TSS appears reasonable. 


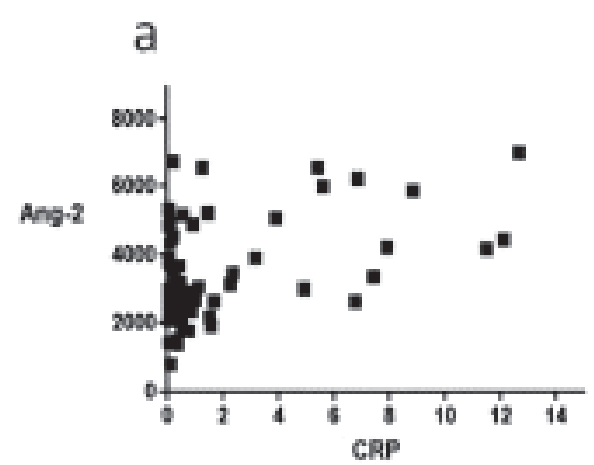

$$
\begin{aligned}
& r=0.3288 \\
& P=0.0055
\end{aligned}
$$

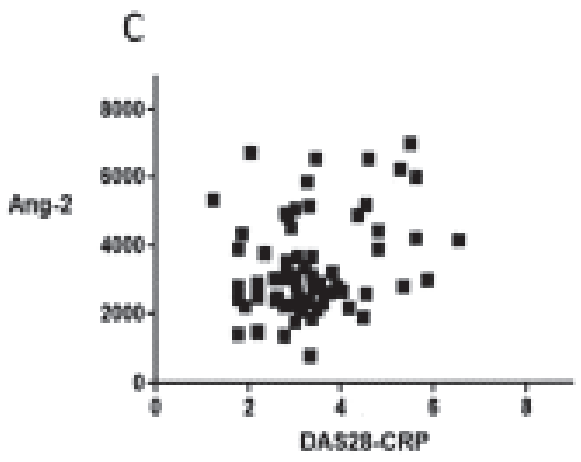

$r=0.2147$

$P=0.0743$ b

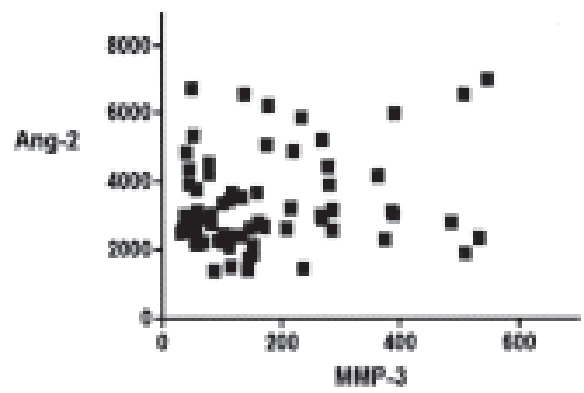

$\mathrm{r}=0.1035$

$P=0.4081$

d

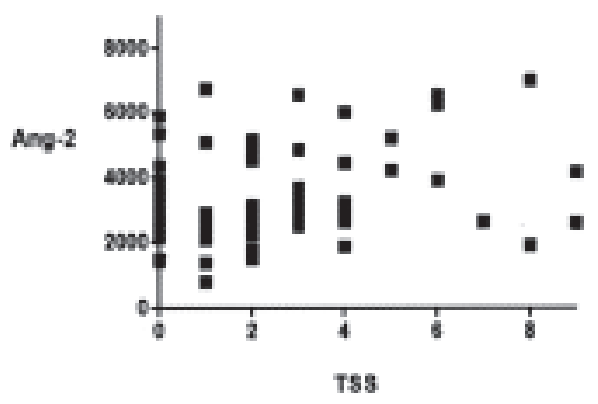

$r=0.2790$

$P=0.0193$

Figure 3. Relationships of serum angiopoietin-2 (Ang-2) level with indices of RA activity. (a) Serum Ang-2 and C-reactive protein (CRP) levels. (b) Serum Ang-2 and matrix metalloprotease (MMP)-3 levels. (c) Serum Ang-2 level and the 28-joint count Disease Activity Score (DAS28)-CRP. (d) Serum Ang-2 level and total signal score (TSS). Serum Ang-2 level was correlated with the serum CRP level and TSS. It was not correlated with the serum MMP-3 level or DAS28-CRP.

The serum VEGF level was correlated with all 4 measures of RA activity examined in our study. Therefore, the serum VEGF level is considered useful as an index of RA activity and a predictive factor for joint destruction based on angiogenesis.

The correlations of the serum Ang-1 and Ang-2 levels with indices of RA activity were weaker than the correlations of the serum VEGF level, and their clinical significance was difficult to determine. A close examination of the data revealed a comparison between the serum Ang-1 and Ang-2 levels that was of interest. The serum Ang-1 level was correlated with the serum MMP-3 level but not with the serum CRP level. The serum Ang-2 level, on the other hand, was correlated with the serum CRP level but not with the serum MMP-3 level. While the serum MMP-3 level reflects disease activity, it is less useful than the serum CRP level as a disease activity marker. But the serum MMP-3 level correlates closely with the outcome of patients with RA, particularly the degree of radiological joint destruction. Thus, the serum MMP-3 level is an index of sustained arthritis and is useful as a predictive factor for the radiological outcome of RA. In contrast, serum CRP level is considered to be most useful as an index of disease activity on examination. The serum level of Ang-1, which is important for the maintenance of newly formed vessels, is related to indices of sustained arthritis, and the serum level of Ang-2, which is important in marked angiogenesis, is related to indices of disease activity on examination.

While DAS28-CRP was correlated with the serum Ang-1 level but not the serum Ang-2 level, the p or $r$ value showed no marked difference, and the correlations of DAS28-CRP with the serum Ang-1 and Ang-2 levels were weaker than those of the VEGF level. Serum Ang-1 and Ang-2 levels are considered to be less sensitive indices of RA activity than the serum VEGF level.

The relationship with the TSS also differed between the serum Ang-1 and Ang- 2 levels. The TSS correlated with the level of Ang-2 but not with the Ang-1 level. Synovial blood flow signals have been observed to be related to angiogenesis. It remains unclear in which period it is related more Personal non-commercial use only. The Journal of Rheumatology Copyright $@$ ( 2010. All rights reserved. 

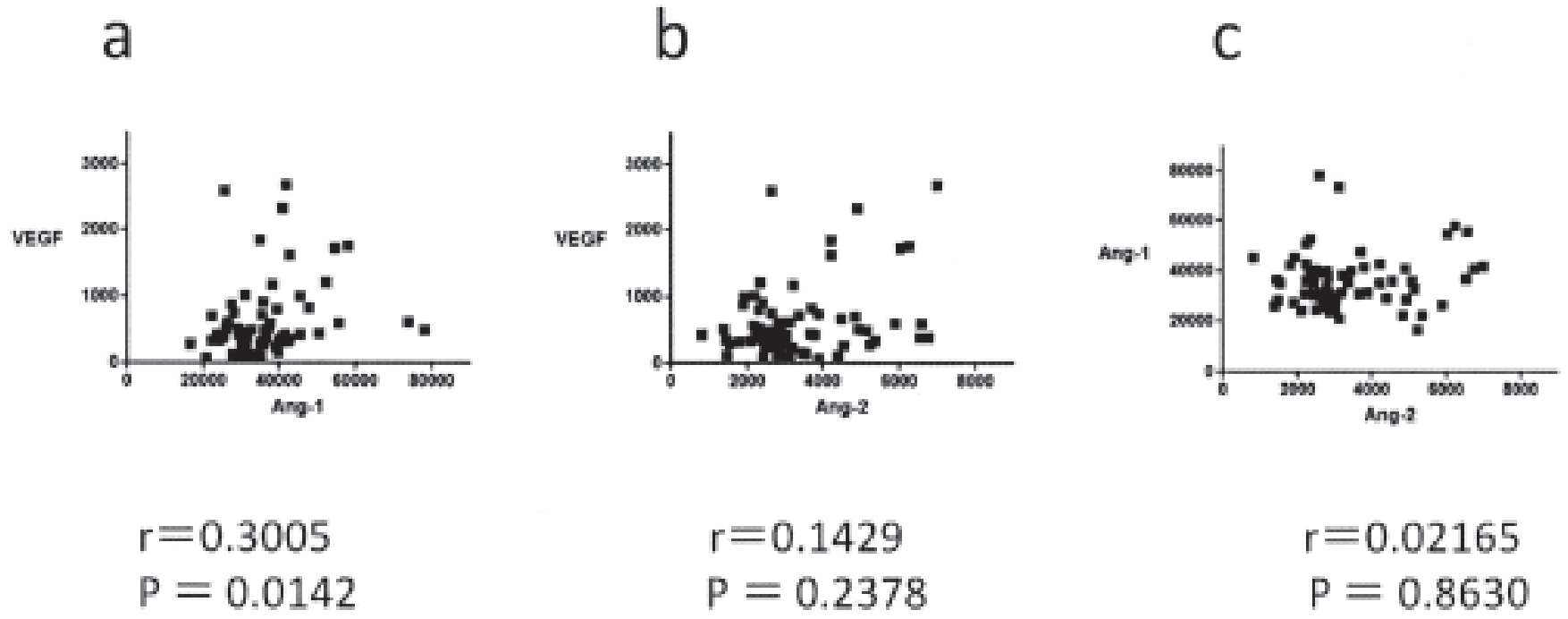

Figure 4. Relationships among angiogenic factors. (a) Serum vascular endothelial growth factor (VEGF) and angiopoietin-1 (Ang-1) levels. (b) Serum VEGF and angiopoietin-2 (Ang-2) levels. (c) Serum Ang-1 and Ang-2 levels. A correlation was observed between the serum VEGF and Ang-1 levels but not between the serum VEGF and Ang-2 levels or between the serum Ang-1 and Ang-2 levels.

closely to angiogenesis. Since the TSS correlated with Ang-2 but not with Ang-1, synovial blood flow signals are considered to represent angiogenesis particularly in a phase of the disease showing vigorous angiogenesis. Synovial blood flow signals have been seen to fluctuate dynamically, responding to various treatments, particularly treatment with tumor necrosis factor- $\alpha$ inhibitors ${ }^{28-30}$. The data from our study may explain this.

Among the angiogenic factors we examined, a correlation was observed between the serum levels of VEGF and of Ang-1 but not in the other combinations. The absence of a correlation between the serum Ang-1 and Ang-2 levels is understandable based on other data. The correlation of VEGF level with the level of Ang-1 rather than the level of Ang-2 may indicate the usefulness of the serum VEGF level as an index of sustained arthritis.

\section{REFERENCES}

1. Paleolog EM, Fava RA. Angiogenesis in rheumatoid arthritis: implications for future therapeutic strategies. Springer Semin Immunopathol 1998;20:73-94.

2. Walsh DA. Angiogenesis and arthritis. Rheumatology 1999;38:103-12.

3. Koch AE. Angiogenesis as a target in rheumatoid arthritis. Ann Rheum Dis 2003;62 Suppl 2:ii60-7.

4. Taylor PC. VEGF and imaging of vessels in rheumatoid arthritis. Arthritis Res 2002;4 Suppl 3:S99-107.

5. Neufeld G, Cohen T, Gengrinovitch S, Poltorak Z. Vascular endothelial growth factor (VEGF) and its receptors. FASEB J 1999;13:9-22.

6. Fava RA, Olsen NJ, Spencer-Green G, Yeo KT, Yeo TK, Berse B, et al. Vascular permeability factor/endothelial growth factor (VPF/VEGF): accumulation and expression in human synovial fluids and rheumatoid synovial tissue. J Exp Med 1994;180:341-6.

7. Ballara S, Taylor PC, Reusch P, Marmé D, Feldmann M, Maini RN, et al. Raised serum vascular endothelial growth factor levels are associated with destructive change in inflammatory arthritis. Arthritis Rheum 2001;44:2055-64.

8. Clavel G, Bessis N, Lemeiter D, Fardellone P, Mejjad O, Ménard $\mathrm{JF}$, et al. Angiogenesis markers (VEGF, soluble receptor of VEGF and angiopoietin-1) in very early arthritis and their association with inflammation and joint destruction. Clin Immunol 2007; $124: 158-64$.

9. Fiedler U, Augustin HG. Angiopoietins: a link between angiogenesis and inflammation. Trends Immunol 2006;27:552-8.

10. Stratmann A, Risau W, Plate KH. Cell type-specific expression of angiopoietin-1 and angiopoietin-2 suggests a role in glioblastoma angiogenesis. Am J Pathol 1998;153:1459-66.

11. Oh H, Takagi H, Suzuma K, Otani A, Matsumura M, Honda Y. Hypoxia and vascular endothelial growth factor selectively up-regulate angiopoietin-2 in bovine microvascular endothelial cells. J Biol Chem 1999;274:15732-9.

12. Mandriota SJ, Pyke C, Di Sanza C, Quinodoz P, Pittet B, Pepper MS. Hypoxia-inducible angiopoietin-2 expression is mimicked by iodonium compounds and occurs in the rat brain and skin in response to systemic hypoxia and tissue ischemia. Am J Pathol 2000;156:2077-89.

13. Scharpfenecker M, Fiedler U, Reiss Y, Augustin HG. The Tie-2 ligand angiopoietin-2 destabilizes quiescent endothelium through an internal autocrine loop mechanism. J Cell Sci 2005;118 part 4:771-80.

14. Fiedler U, Reiss Y, Scharpfenecker M, Grunow V, Koidl S, Thurston G, et al. Angiopoietin-2 sensitizes endothelial cells to TNF-alpha and has a crucial role in the induction of inflammation. Nat Med 2006;12:235-9.

15. Scott BB, Zaratin PF, Colombo A, Hansbury MJ, Winkler JD, Jackson JR. Constitutive expression of angiopoietin-1 and -2 and modulation of their expression by inflammatory cytokines in rheumatoid arthritis synovial fibroblasts. J Rheumatol 2002;29:230-9.

16. Gravallese EM, Pettit AR, Lee R, Madore R, Manning C, Tsay A, et al. Angiopoietin-1 is expressed in the synovium of patients with rheumatoid arthritis and is induced by tumour necrosis factor alpha. Ann Rheum Dis 2003;62:100-7.

17. Fearon U, Griosios K, Fraser A, Reece R, Emery P, Jones PF, et al. 
Angiopoietins, growth factors, and vascular morphology in early arthritis. J Rheumatol 2003;30:260-8.

18. Arnett FC, Edworthy SM, Bloch DA, McShane DJ, Fries JF, Cooper NS, et al. The American Rheumatism Association 1987 revised criteria for the classification of rheumatoid arthritis. Arthritis Rheum 1988;31:315-24.

19. Ribbens C, Andre B, Jaspar JM, Kaye O, Kaiser MJ, De Groote D, et al. Matrix metalloproteinase-3 serum levels are correlated with disease activity and predict clinical response in rheumatoid arthritis. J Rheumatol 2000;27:888-93.

20. van der Heijde DM, van 't Hof M, van Riel PL, van de Putte LB. Development of a disease activity score based on judgment in clinical practice by rheumatologists. J Rheumatol 1993;20:579-81.

21. Naredo E, Collado P, Cruz A, Palop MJ, Cabero F, Richi P, et al. Longitudinal power Doppler ultrasonographic assessment of joint inflammatory activity in early rheumatoid arthritis: predictive value in disease activity and radiologic progression. Arthritis Rheum 2007;57:116-24.

22. Naredo E, Möller I, Cruz A, Carmona L, Garrido J. Power Doppler ultrasonographic monitoring of response to anti-tumor necrosis factor therapy in patients with rheumatoid arthritis. Arthritis Rheum 2008;58:2248-56.

23. Naredo E, Rodríguez M, Campos C, Rodríguez-Heredia JM, Medina JA, Giner E, et al; Ultrasound Group of The Spanish Society of Rheumatology. Validity, reproducibility, and responsiveness of a twelve-joint simplified power doppler ultrasonographic assessment of joint inflammation in rheumatoid arthritis. Arthritis Rheum 2008;59:515-22.

24. Yamanaka H, Matsuda Y, Tanaka M, Sendo W, Nakajima H, Taniguchi A, et al. Serum matrix metalloproteinase 3 as a predictor of the degree of joint destruction during the six months after measurement, in patients with early rheumatoid arthritis. Arthritis Rheum 2000;43:852-8.

25. Kurosaka D, Hirai K, Nishioka M, Miyamoto Y, Yoshida K, Takahashi E, et al. Correlation between synovial blood flow signals and serum vascular endothelial growth factor levels in patients with refractory rheumatoid arthritis. Mod Rheumatol 2009;19:187-91.

26. Strunk J, Heinemann E, Neeck G, Schmidt KL, Lange U. A new approach to studying angiogenesis in rheumatoid arthritis by means of power Doppler ultrasonography and measurement of serum vascular endothelial growth factor. Rheumatology 2004;43:1480-3.

27. Walther M, Harms H, Krenn V, Radke S, Faehndrich TP, Gohlke F. Correlation of power Doppler sonography with vascularity of the synovial tissue of the knee joint in patients with osteoarthritis and rheumatoid arthritis. Arthritis Rheum 2001;44:331-8.

28. Hau M, Kneitz C, Tony HP, Keberle M, Jahns R, Jenett M. High resolution ultrasound detects a decrease in pannus vascularisation of small finger joints in patients with rheumatoid arthritis receiving treatment with soluble tumour necrosis factor alpha receptor (etanercept). Ann Rheum Dis 2002;61:55-8.

29. Terslev L, Torp-Pedersen S, Qvistgaard E, Kristoffersen H, Røgind H, Danneskiold-Samsøe B, et al. Effects of treatment with etanercept (Enbrel, TNRF:Fc) on rheumatoid arthritis evaluated by Doppler ultrasonography. Ann Rheum Dis 2003;62:178-81.

30. Fiocco U, Ferro F, Vezzù M, Cozzi L, Checchetto C, Sfriso P, et al. Rheumatoid and psoriatic knee synovitis: clinical, grey scale, and power Doppler ultrasound assessment of the response to etanercept. Ann Rheum Dis 2005;64:899-905. 